\title{
A Method Validation Procedure for Some Quality Parameters in Goat Milk
}

\author{
İrem KARAASLAN¹, Baran ÇAMDEVİREN², Hüseyin ÖZKAN³, Akın YAKAN11,3* \\ ${ }^{1}$ Hatay Mustafa Kemal University, Technology and Research \& Development Center (MARGEM), 31040, Hatay, Turkey \\ ${ }^{2}$ Hatay Mustafa Kemal University, Faculty of Veterinary Medicine, Genetic Laboratory, 31040, Hatay, Turkey \\ ${ }^{3}$ Hatay Mustafa Kemal University, Faculty of Veterinary Medicine, Department of Genetic, 31040, Hatay, Turkey
}

\begin{abstract}
Goat milk has great importance in human health and nutrition. It may be used to manufacture wide variety of products due to its chemical characteristics. In this study, an easy and quick method for the analysis of fat, fat-free dry matter (FFDM), lactose, protein percentage, electrical conductivity, freezing point and density in milk was validated. The repeatability values determined by the operators were 4.65 and 4.68 for lactose; 3.10 for protein, 4.38 and 4.33 for fat; 8.52 and 8.55 for FFDM. The same values for reproducibility were 4.78; 3.17 and 3.18; 4.38 and $4.39 ; 8.73$ and 8.75 , respectively. There was no significant difference between the data obtained by the operators in all parameters subject to the study $(\mathrm{P}>0.05)$. Horwitz ratio (HorRat) was used as comparison for reproducibility. HorRat values are required to be less than 2. HorRat values determined in all parameters measured in this study were between 0.25 and 0.94 . Finally, the expanded uncertainty and the combined standard uncertainty were calculated. By the way, the present study provided a fast, and reliable protocol for these analysis. Further research is needed to gain knowledge on the suitability and advantages of the usage of validated method approach for different goat milk components.
\end{abstract}

Keywords: Goat, Milk composition, Method validation

\section{Keçi Sütünde Bazı Kalite Parametreleri İçin Metot Validasyonu}

ÖZ

Keçi sütü insan sağlığ1 ve beslenmesinde büyük öneme sahiptir. Kimyasal özelliklerinden dolayı, keçi sütü, çok çeşitli ürünlerin üretiminde kullanılabilir. Bu çalısmada, Şam keçisinin sütündeki yağ, yağsız kuru madde (YKM), laktoz, protein oranı, elektriksel iletkenlik, donma noktası ve yoğunluk analizi için kolay ve hızlı bir yöntem geçerli kilınmıştır. Operatörler tarafindan tespit edilen tekrarlanabilirlik değerleri, laktoz için 4.65 ve 4.68; protein için 3.10; yağ için 4.38 ve 4.33; YKM için 8.52 ve 8.55 olmuştur. Aynı değerler tekrarüretilebilirlik için sırasıyla, 4.78; 3.17 ve 3.18 ; 4.38 ve 4.39 ; 8.73 ve 8.75 olarak tespit edilmiştir. Çalışmaya konu olan tüm parametrelerde, operatörler tarafından elde edilen veriler arasındaki farklıı önemli olmamıştır ( $\mathrm{P}>0.05)$. Horwitz oranı (HorRat) tekrar üretilebilirlik için karşılaştırma yapılmasında kullanılmıştır. HorRat değerlerinin 2'den küçük olması istenir. Bu çalışmada ölçülen tüm parametrelerde belirlenen HorRat değerleri 0.25 ile 0.94 arasında olmuştur. Son olarak, her bir parametre için birleşik belirsizlik ve genişletilmiş belirsizlik hesaplanmıştır. Böylelikle, bu çalısma, bazı süt kalite parametrelerinin analizleri için hızlı ve güvenilir bir protokol sağlamıştır. Geçerli kıllınmış yöntem yaklaşımının kullanımının uygunluğu ve avantajları hakkında bilgi edinmek amacıyla, farklı keçi sütü bileşenleri için daha fazla araştırmaya ihtiyaç vardır.

Anahtar Kelimeler: Keçi, Süt kompozisyonu, Metot validasyonu

To cite this article: Karaaslan I. Camdeviren B. Örkan H. Yakan A. A Method Validation Procedure for Some Quality Parameters in Goat Milk. Kocatepe Vet J. (2020) 13(4):357-361

Submission: 20.08.2020 Accepted: 19.10.2020 Published Online: 10.11.2020

ORCID ID; IK: 0000-0002-7485-192X, BC: 0000-0003-1508-7869, HÖ:0000-0001-5753-8985, AY: 0000-0002-9248-828X

*Corresponding author e-mail: yakan@mku.edu.tr 


\section{INTRODUCTION}

Thousands of tests and analysis are needed every day in different laboratories around the world. The cost of these analytical methods is too high and they are mostly time consuming (Magnusson 2014). Therefore, for an analytical method, it is very important to be suitable for its intended use (Hopfgartner 2020). On the other hand, since the decision taken based on the result must be sufficiently reliable, the method must ensure that every result of the measurement is close enough to the unknown correct result. (González and Herrador 2007). If method performance is validated and the uncertainty on the result, at a given level of confidence, estimated, an analytical result is accompanied by indication of the correct results and data quality (Magnusson 2014).

Method validation is an essential component of the analytical measurements for the laboratories to produce analytical data of high quality with confidence (Mohamed et al., 2020). Validation procedure demonstrates that an analytical method is appropriate for purpose and evaluates risks of measurements (Anonymous 2005). It provides precision knowledge and experience of performing the method. The analytical requirements, critical steps in the process are clearly defined and method capabilities are confirmed by validation (Magnusson 2014). Thus the steps necessary, the specific matrices, the reference standard and the reagents will be used should be described in details to perform each analytical test (Mohamed et al., 2020).

Milk and milk products are essential food sources dependent on all of the basic nutrients they have (Niero et al., 2017; Lu et al., 2020). People with cow's milk allergy consume goat milk because of its known beneficial and therapeutic effects on them (Ribeiro et al., 2010). Goat milk's digestibility is higher than cow milk (Luna et al., 2008; Schettino et al., 2017; Mazzaglia et al., 2020). These nutritional, healthy and therapeutic benefits increase goat milk's and its products's importance for the human health and also for markets (Silanikove et al., 2010; Serhan et al., 2016).

Due to growing commercial interest in production and characterization of goat milk, the accuracy of its composition has great importance (Costa et al., 2015). Besides their effects on health, milk composition influence technological traits of milk. Extensive milk products attributes milk composition variability (Franzoi et al., 2018). For goat milk, its tolerance for technological processes, its properties (being healthy, secure, hygienic) and its nutritional value, sensory attributes may define its quality (Ribeiro et al., 2010). Non-fat solids in goat milk, provide satisfactory curd tension (Martín-Diana et al., 2003). Fat and proteins are one of the most important components of goat milk in terms nutritional quality. Goat dairy products's color and flavor are affected from its lipid ratio (Niero et al., 2017). In addition, carbohydrates could be an excellent substitute for human milk carbohydrates (Slačanac et al., 2010). Since milk quality is significant for manufacturing dairy products in high quality, a successful strategy for measuring parameters are needed.

Investigation of these components separately is difficult, because it implies time consuming and more expensive methodologies. Moreover, it would be more difficult to attribute to analysis. Since, cow milk is mainly used for manufacturing traditional milk products (Mazzaglia et al., 2020), there are lots of research in which cow milk is a matrice used and the methods used for the measurements of its characteristics are validated. However, although, goat milk production is a growing industry, their validation for milk quality parameters are very limited. Therefore, the aim of this study was to validate a simple, robust, fast and cost-effective method for the determination of fat, fat-free dry matter (FFDM), lactose, protein percentage, electrical conductivity, freezing point and density of goat milk.

\section{MATERIALS and METHODS}

\section{Sample Collection and Parameter Measurement}

This study was conducted in the laboratory of Genetic Department, Faculty of Veterinary Medicine, Hatay Mustafa Kemal University. In the study, a total of 4.5 liters of milk sample were collected from 10 Damascus goats. Animals were 2-4 years old. Generally, health conditions of the goats were good and they did not have mastitis. Milk sample was taken during routine milking procedure in $4-5^{\text {th }}$ months of the lactation. The goats spent the day on the pasture and the night on the pen, and they always had access to fresh water in both the pasture and the pen. During morning milking, samples were collected, brought to the laboratory by a cold chain of $+4{ }^{\circ} \mathrm{C}$ in approximately 15 minutes. Before studied, collected milk was divided into 30 subsamples of $150 \mathrm{ml}$ and stored at $+4{ }^{\circ} \mathrm{C}$ during validation process. For each measurement, only the subsamples were used were taken and then analyzed for fat, fat-free dry matter (FFDM), lactose, protein percentage, electrical conductivity, freezing point, density (Milkotester Master Classic LM2 P1 - Bulgaria).

\section{Method Validation Process}

EURACHEM guidelines was used for method validation parameters (Magnusson 2014). In this study, repeatability and reproducibility were considered for the method precision. Repeatability was conducted as soon as milk samples are brought to the laboratory. 16 measurements on 16 subsamples, were separately processed within the 
same day by 2 different operators who handled 8 subsamples each. Since the device manual declares a measurement accuracy of 48 hours, reproducibility study was carried out within a period of 48 hours. For reproducibility, 14 measurements on 14 subsamples, were separately processed after $0,8,16,24,32,40$, and 48 hours by 2 different operators who handled 7 subsamples each.

\section{Estimation of measurement uncertainty}

The uncertainty $\mathrm{U}(\mathrm{P})$ was obtained by identifying, quantifying and combining all individual contributions to uncertainty (Eq. 1). The relative expanded uncertainty, uncertainty expressed as a relative standard deviation, was calculated by using the covarage factors (k), repeatability and reproducibility, of 2 at $95 \%$ confidence level.

$$
\mathrm{U}(\mathrm{P})=\sqrt{(\text { repeatability })^{2}+{\text { (reproducibility })^{2}}^{2}}
$$

\section{Statistical analysis}

Repeatability was calculated as the relative standard deviation $\left(\mathrm{RSD}_{\mathrm{r}}\right)$ of measurements within the same day. Similarly, reproducibility was calculated as the relative standard deviation $\left(\mathrm{RSD}_{\mathrm{R}}\right)$ of measurements obtained across the different times of analyses, as proposed in EURACHEM guidelines (Magnusson 2014). Also, the Horwitz ratio (HorRat) was calculated for comparison of reproducibility (Eq. 2).

$$
\text { HorRat }=\frac{\text { RSD }_{\mathbb{R}}}{\text { PRSD }_{\text {I }}}
$$

\section{RESULTS AND DISCUSSION}

In order to confirm that a method is suitable for certain applications and that it provides reliable outcomes, method validation performance parameters must be evaluated and complied with certain legal requirements (Leite et al., 2020). In this study, several guidance documents on the performance of analytical methods with different concepts used to confirm the validation parameters.

The precision of the method for the determination of fat, FFDM, lactose, protein percentage and electrical conductivity, freezing point, density of milk were assessed through repeatability relative standard deviation $\left(\mathrm{RSD}_{\mathrm{r}}\right)$ and reproducibility relative standard deviation $\left(\mathrm{RSD}_{\mathrm{R}}\right)$. RSD is the ratio between the standard deviation and mean.

All of the quality parameters measured for the purpose of repeatability of milk in the study were within the values of goat reported in the literature (Yakan et al., 2019; Slačanac et al., 2010) (Table 1). In addition, there was no statistically significant difference between operator results. The good precision both within and between days reached in the present study could be partly due to the success of the operators in their own data as a result of paying attention the steps of the measurements, like clearness of equipments, time needed for the measurement etc.

Values of $\mathrm{RSD}_{\mathrm{r}}$ and $\mathrm{RSD}_{\mathrm{R}}$ showed good precision both within and between days (Table 1). When the
The Horwitz ratio (HorRat) is a normalized performance parameter indicating the acceptability of methods of analysis with respect to among-laboratory precision (reproducibility) (Horwitz and Albert 2006). Student t-test was used in SPSS 22.0 package program to test the significance of differences between operators in term of milk quality parameters. $\mathrm{P}<0.05$ was accepted as the level of significance.

$\mathrm{RSD}_{\mathrm{r}}$ values for $1^{\text {st }}$ and $2^{\text {nd }}$ operator's results were calculated, it was determined that the $\mathrm{RSD}_{\mathrm{r}}$ values were 0.42 and $0.43 ; 1.18$ and $0.87 ; 0.92$ and $1.02 ; 0.93$ and $1.88 ; 0.48$ and $0.64 ; 0.43$ and 0.48 for freezing point, lactose, protein, fat, FFDM and density, respectively. On the other hand, freezing point $\mathrm{RSD}_{\mathrm{R}}$ were 0.96 and 1.08; electrical conductivity $\mathrm{RSD}_{\mathrm{R}}$ were 0.83 and 0.84 ; lactose $\mathrm{RSD}_{\mathrm{R}}$ were 1.10 and 1.08; protein $\mathrm{RSD}_{\mathrm{R}}$ were 1.29 and 1.32; fat $\mathrm{RSD}_{\mathrm{R}}$ were 0.93 and 0.46 ; FFDM RSD $\mathrm{R}_{\mathrm{R}}$ were 0.79 and 1.02 ; density $\mathrm{RSD}_{\mathrm{R}}$ were 0.83 and 1.18 as a result of $1^{\text {st }}$ and $2^{\text {nd }}$ operator's reproducibility measurements respectively. Overall, the results of the present study were acceptable according to the IUPAC Technical Report (Thompson et al., 2006).

In the study, HorRat was used as comparison for reproducibility of the experimental and the expected RSDR (Franzoi et al., 2018). HorRat values should be in the desirable range $(<2)$ (Horwitz and Albert 2006). All values obtained for milk quality parameters in this study were below the desired range of $<2$. This confirmed the accuracy of measurements of validation.

During the validation study of the analytical procedure, the precision uncertainty sources had been thoroughly investigated. Both uncertainties were combined to obtain a representative or single estimation of precision uncertainty. Precision uncertainty $\mathrm{U}(\mathrm{P})$ values were as $0.0046,0.0055$, $0.0065,0.0069,0.0074,0.0045$, and 0.0047 for freezing point, electrical conductivity, lactose, protein, fat, FFDM, and density of milk, respectively. Finally, 
the expanded uncertainty was calculated by multiplying the combined standard uncertainty with a coverage factor of 2 with a confidence level of $95 \%$ and the values are summarized in Table 2.

The uncertainty values are so important for the exact results of the parameters. When, a result of lactose is
$4.67 \%$ for example, it should be evaluated that, it is $4.67 \% \pm 0.0130$ actually. Another example, protein percentage, should be considered as $3.15 \% \pm 0.0139$ while the measurement value is 3.15. This is very important while reporting the analysis.

Table 1: Precision Data of Measured Parameters (Means $\pm \%$ RSD)

\begin{tabular}{|c|c|c|c|c|c|c|c|}
\hline \multirow{2}{*}{ Parameter } & \multicolumn{2}{|l|}{ Repeatability } & \multirow{2}{*}{$\begin{array}{l}\mathbf{P} \\
\text { Values }\end{array}$} & \multicolumn{2}{|c|}{ Reproducibility } & \multirow{2}{*}{$\begin{array}{l}\mathbf{P} \\
\text { Values }\end{array}$} & \multirow{2}{*}{ HorRat } \\
\hline & 1st Operator & $2^{\text {nd }}$ Operator & & $1^{\text {st }}$ Operator & $2^{\text {nd }}$ Operator & & \\
\hline Freezing Point $\left({ }^{\circ} \mathrm{C}\right)$ & $0.58 \pm 0.42$ & $0.58 \pm 0.43$ & 0.06 & $0,59 \pm 0.96$ & $0.59 \pm 1.08$ & 0.85 & 0.55 \\
\hline $\begin{array}{l}\text { E. Conductivity } \\
(\mathrm{mS} / \mathrm{cm})\end{array}$ & $4.98 \pm 0.82$ & $4.97 \pm 1.04$ & 0.14 & $4.92 \pm 0.83$ & $4.88 \pm 0.84$ & 0.18 & 0.81 \\
\hline Lactose (\%) & $4.65 \pm 1.18$ & $4.68 \pm 0.87$ & 0.06 & $4.78 \pm 1.10$ & $4.78 \pm 1.08$ & 0.78 & 0.82 \\
\hline Protein $(\%)$ & $3.10 \pm 0.92$ & $3.10 \pm 1.02$ & 0.84 & $3.17 \pm 1.29$ & $3.18 \pm 1.32$ & 0.90 & 0.81 \\
\hline Fat $(\%)$ & $4.38 \pm 0.93$ & $4.33 \pm 1.88$ & 0.21 & $4.38 \pm 0.93$ & $4.39 \pm 0.46$ & 0.34 & 0.25 \\
\hline FFDM $(\%)$ & $8.52 \pm 0.48$ & $8.55 \pm 0.64$ & 0.53 & $8.73 \pm 0.79$ & $8.75 \pm 1.02$ & 0.59 & 0.83 \\
\hline Density $\left(\mathrm{kg} / \mathrm{m}^{3}\right)$ & $28.27 \pm 0.43$ & $28.45 \pm 0.48$ & 0.06 & $29.04 \pm 0.83$ & $29.04 \pm 1.18$ & 0.91 & 0.94 \\
\hline
\end{tabular}

RSD: Relative Standard Deviation; FFDM: Fat-free Dry Matter; E. Conductivity: Electrical Conductivity

Table 2: Precision Uncertainties, Combined Standard Uncertainty and Expanded Uncertainty of Measured Parameters

\begin{tabular}{lllll}
\hline Parameter & $\begin{array}{l}\text { Repeatability } \\
\text { Uncertainty }\end{array}$ & $\begin{array}{l}\text { Reproducibility } \\
\text { Uncertainty }\end{array}$ & $\begin{array}{l}\text { Combined } \\
\text { Uncertainty }\end{array}$ & $\begin{array}{c}\text { Standard Expanded } \\
\text { Uncertainty }\end{array}$ \\
\hline Freezing Point $\left({ }^{\circ} \mathrm{C}\right)$ & 0.0019 & 0.0042 & 0.0046 & 0.0092 \\
E. Conductivity $(\mathrm{mS} / \mathrm{cm})$ & 0.0043 & 0.0034 & 0.0055 & 0.0109 \\
Lactose $(\%)$ & 0.0047 & 0.0044 & 0.0065 & 0.0130 \\
Protein $(\%)$ & 0.0044 & 0.0053 & 0.0069 & 0.0139 \\
Fat $(\%)$ & 0.0068 & 0.0030 & 0.0074 & 0.0148 \\
FFDM $(\%)$ & 0.0026 & 0.0037 & 0.0045 & 0.0091 \\
Density $\left(\mathrm{kg} / \mathrm{m}^{3}\right)$ & 0.0021 & 0.0042 & 0.0047 & 0.0093 \\
\hline
\end{tabular}

FFDM: Fat-free Dry Matter; E. Conductivity: Electrical Conductivity

\section{CONCLUSION}

In conclusion, the present study provided a fast, reliable and succesfully validated protocol for analysing fat, FFDM, lactose, protein percentage, electrical conductivity, freezing point and density of goat milk. The method showed good precision which acceptable under the validation criteria of EURACHEM guidelines and IUPAC Technical Report. The proposed method can effectively apply for the routine analysis of the parameters studied in this study. Further research is needed to gain knowledge on the suitability and advantages of the usage of validated method approach for different goat milk components.

\section{REFERENCES}

Anonymous. ICH Harmonised Tripartite Guide: Validation of analytical procedures: text and methodology. Q2 (R1) 2005; 1:1-15.

Costa MP, Frasao BS, Silva ACO, Freitas MQ, Franco RM, Conte-Junior CA. Cupuassu (Theobroma grandiflorum) pulp, probiotic, and prebiotic: Influence on color, apparent viscosity, and texture of goat milk yogurts. Int. J. Dairy Sci. 2015; 98(9):5995-6003.

Franzoi M, Niero G, Penasa M, Cassandro M, De Marchi M. Development and validation of a new method for the quantification of soluble and micellar calcium, magnesium, and potassium in milk. Int. J. Dairy Sci. 2018; 101(3):1883-1888. 
González AG, Herrador MÁ. A practical guide to analytical method validation, including measurement uncertainty and accuracy profiles. Trac-Trend Anal Chem 2007; 26(3):227-238.

Hopfgartner G. Bioanalytical method validation: How much should we do and how should we document? Anal. Bioanal. Chem. 2020; 412:531-532

Horwitz W, Albert R. The Horwitz ratio (HorRat): A useful index of method performance with respect to precision. J AOAC Int. 2006;89(4):1095-109.

Leite M, Freitas A, Silva AS, Barbosa J, Ramos F. Maize (Zea mays L.) and mycotoxins: A review on optimization and validation of analytical methods by liquid chromatography coupled to mass spectrometry. Trends Food Sci Tech 2020; 99:542-565

Lu J, Zhang Y, Song B, Zhang S, Pang X, Sari RN, Lv J. Comparative analysis of oligosaccharides in Guanzhong and Saanen goat milk by using LC-MS/MS. Carbohydr. Polym. 2020; 235:115965.

Luna P, Bach A, Juárez M, De La Fuente MA. Effect of a diet enriched in whole linseed and sunflower oil on goat milk fatty acid composition and conjugated linoleic acid isomer profile. Int. J. Dairy Sci. 2008; 91(1):20-28.

Magnusson B, Örnemark U. Eurachem Guide: The fitness for purpose of analytical methods - A laboratory guide to method validation and related topics, 2 nd Ed., Eurachem. 2014.

Martín-Diana AB, Janer C, Peláez C, Requena T. Development of a fermented goat's milk containing probiotic bacteria. Int. Dairy J. 2003; 13(10):827-833.

Mazzaglia A, Legarov V, Giaquinta R, Lanza CM, Restuccia C. The influence of almond flour, inulin and whey protein on the sensory and microbiological quality of goat milk yogurt. LWT 2020; 124:109138.

Mohamed R, Zainudin BH, Yaakob AS. Method validation and determination of heavy metals in cocoa beans and cocoa products by microwave assisted digestion technique with inductively coupled plasma mass spectrometry. Food Chem 2020; 303:125392.

Niero G, Penasa M, Currò S, Masi A, Trentin AR, Cassandro M, De Marchi M. Development and validation of a near infrared spectrophotometric method to determine total antioxidant activity of milk. Food Chem 2017; 220:371-376.

Ribeiro AC, Ribeiro SDA. Specialty products made from goat milk. Small Ruminant Res 2010; 89(2-3):225-233.

Schettino B, Vega S, Gutiérrez R, Escobar A, Romero J, Domínguez González-Ronquillo M. Fatty acid profile of goat milk in diets supplemented with chia seed (Salvia hispanica L.). Int. J. Dairy Sci. 2017; 100(8):6256-6265.

Serhan M, Mattar J, Debs L. Concentrated yogurt (Labneh) made of a mixture of goats' and cows' milk: Physicochemical, microbiological and sensory analysis. Small Ruminant Res 2016; 138:46-52.

Silanikove N, Leitner G, Merin U, Prosser CG. Recent advances in exploiting goat's milk: quality, safety and production aspects. Small Ruminant Res 2010; 89(23):110-124.

Slačanac V, Božanić R, Hardi J, Rezessyné Szabó JUDIT, Lučan M, Krstanović V. Nutritional and therapeutic value of fermented caprine milk. Int. J. Dairy Technol. 2010; 63(2):171-189.

Thompson M, Ellison SL, Wood R. The International Harmonized Protocol for the proficiency testing of analytical chemistry laboratories (IUPAC Technical Report). Pure Appl. Chem. 2006; 78(1):145-196.

Yakan A, Özkan H, Şakar AE, Ateş CT, Ünal N, Koçak Ö, Özbeyaz C. Milk yield and quality traits in different lactation stages of Damascus goats: Concentrate and pasture based feeding systems. Ankara Üniv Vet Fak Derg 2019; 66: 117-29. 